\title{
PRICING OF BT COTTON SEEDS IN INDIA: THE DEBATE BEHIND
}

\author{
Anchal ARORA
}

\begin{abstract}
Address:
Centre for International Trade and Development, School of International Studies, Jawaharlal Nehru University. NewDelhi-110067, India. e-mail: arora.anchal@yahoo.com
\end{abstract}

\begin{abstract}
In 2006 the state government of Andhra Pradesh reduced the Bt cotton seed prices from Indian Rs1600 to Rs750 in order to make the technology affordable and accessible to small and marginal farmers in the state and also to prevent the monopolistic market structure in the seed market. The drastic reduction in seed prices, on the other hand could affect the profitability of seed providing companies and curb their incentives to innovate in future. Recent literature has also examined the impact of price controls on diffusion of technology, revenue and profitability of seed providers. It suggests that price controls have positively impacted the diffusion of technology in India, and were also successful in increasing the revenue of seed providers in the short run. However, the impact of price controls on profitability would depend on cost conditions. In the light of the above discussion, this article attempts to discuss the debate behind price controls and draws certain policy implications pertaining to pricing of Bt seeds, which has an international policy relevance.
\end{abstract}

Keywords: Bt cotton, seed price reductions, policy

JEL: O33, Q16

\section{THE CURRENT DEBATE}

One of the currently debatable issues pertaining to $\mathrm{Bt}$ crops is the pricing of Bt seeds and its implications for various stakeholders. Two main stakeholders are farmers and seed providing companies. Bt cotton was the first agricultural bio-tech crop that was commercialized in India in 2002 by Mahyco-Monsanto Biotech (MMB) - a joint venture between Mahyco (an Indian firm) and Monsanto (a US based firm). Since then, the area under Bt cotton has increased remarkably from 50,000 hectares in 2002 to 10.6 million hectares in 2011.

Until 2005, MMB dominated the market for cotton hybrids, either directly through selling hybrid seeds or indirectly through sub-licensing to private seed companies. India's regulatory system gave MMB a temporary monopoly on the $\mathrm{Bt}$ gene. MMB derived a measure of protection for its gene through India's biosafety laws. As biosafety approvals are obtained for the composite of the gene and the germ-plasm, hybrids that incorporate MMBs gene but do not go through the biosafety process are considered illegal. The domestic companies that licensed $\mathrm{Bt}$ trait from MMB were required to pay a one-time license fee as well as a royalty fee for availing the gene. This led to a large price differences between $\mathrm{Bt}$ and non-Bt hybrids. The price for official Bt cotton seeds in India in 2006 was around Rs 1,600 per packet of 450 grams, which was around four times the price of non-Bt hybrid. Out of the seed price of Rs 1600 , Rs 1250 was charged by MMB as the trait value or royalty.
The large gap between the price of $\mathrm{Bt}$ cotton hybrid and non-Bt hybrid led to the fears that monopolistic market structure was prevailing in the cotton seed market that has resulted in excessive seed prices. Concerns were raised that high seed prices may restrict access of technology for resource poor farmers (Lalitha, 2004). The state of Andhra Pradesh imposed a ceiling of Rs 750 (inclusive of technology fee) on $\mathrm{Bt}$ cotton seed price in Andhra Pradesh to make the technology affordable and accessible to small and marginal farmers in the state. The other states of India also imposed the same ceiling. Indeed, in the year when the price controls were implemented, adoption rates recorded an increase of $192 \%$ over the previous year. The corresponding increase was $63 \%$ in 2007 , and $23 \%$ in 2008.

The drastic reduction in seed prices, on the other hand, could affect the profitability of the seed providing companies and might curb their incentive to innovate in future. Thus, if seed prices and trait values are fixed at low arbitrary levels, farmers benefits might increase in the short run but the incentive to invest in the development of new technologies might reduce due to shrinking of company revenues.

A member of National Seed Association of India (NSAI) on May 22, 2010 expressed his concern in Financial Express:

"Price restriction would hamper future advancements in germplasm and technologies resulting in non-availability of good quality seeds to the farmers in the future" 
"Since companies have invested heavily in research, if prices are not increased, it would lead to extinction of several companies".

[Recently, keeping in view the rising labour costs and production costs for $\mathrm{Bt}$ cotton and increasing pressure from seed companies, state government of Gujarat and Andhra Pradesh have increased seed prices of both BG-I and BG-II trait to Rs 830 and Rs 930 for a packet of 450gms from Rs 650 and Rs 750 respectively (Times of India, 2011)].

He also said that newer technologies such as drought tolerance and herbicide tolerance ones would not become available to farmers as research costs are also increasing.

If a firm wants to access Bt hybrids it can either license an already approved gene construct from a technology provider, or it can develop its own Bt gene by undertaking research and development. Bt-related investment could be recouped easily if the firm follows the first route and these investments do not act as barriers to entry. Developing one's own Bt genes, on the other hand, is considerably more expensive. In 2006, two Indian seed companies, JK Agri-Genetics Limited and Nath Seeds Limited, opted for the second route and received regulatory approval for their Bt cotton hybrids, which incorporated non-Monsanto genes. It has been argued in the literature that the competition from alternative genes could have a serious impact on seed price. Although the price ceilings were supposedly directed at controlling (MMBs) monopoly pricing, they probably disadvantaged the alternative gene providers JK Agri-Genetics Limited and Nath Seeds Limited even more as their costs couldn't be recouped easily (Murugkar, Ramaswami and Shelar, 2007).

In the light of the above discussion, the following questions arise:

- What has been the impact of price controls on the adoption of the technology?

- 'What has been the impact of seed price controls on the revenue and profitability of the seed providers in India?

- $\quad$ Are these price controls curbing the incentive of the company to innovate in future, which could reduce farmers' ability to get access to new technology, or are these beneficial for the farmers as well as seed providers in terms of increased adoption and profitability from technology?

- Are other policy measures such as encouraging competition in the seed market by allowing more private players to enter, or supporting indigenous research by farmer scientists who develop their own hybrids superior to the policy of seed price controls?

If the prevailing market price for Bt cotton seeds is the profit maximizing price, then a reduction in seed prices cannot increase seed providers' profitability. However, if prices charged are sub-optimal then price controls may result in an increase in profitability. This could be because of the firms' incomplete knowledge of the demand curve for Bt seeds. For example, in Argentina, the prices charged by the firm for Bt cotton seeds were sub-optimal and this was due to the firms lack of assessment of the demand curve (Qaim and de Janvry, 2003). Another possible reason for sub-optimal prices is that the seed prices could be set to maximize global profits rather than local profits.

\section{DIFFERENT VIEWS IN THE LITERATURE}

Recent literature has analyzed implications of different pricing strategies of Bt cotton seeds for farmers and seed providing companies. Analyzing expected level of demand for Bt cotton seeds in Argentina under different pricing regimes, Qaim and de Janvry (2003) find that a high seed price is a barrier to adoption, especially for smallholder farmers. They argue that reducing seed prices would not only increase farmers' profits, but would also be more profitable for the seed producing company.

In contrast to the above paper, analyzing adoption of Bt cotton in India in the light of government seed price interventions, Sadashivappa and Qaim (2009) find a high willingness to pay (close to the official market price) for Bt cotton seeds. According to the study, the take off phase for Bt cotton had already begun before 2006 and thus the government seed price interventions had little impact on aggregate Bt cotton adoption. They apprehend that seed price controls might reduce the incentive of the company to innovate in the future.

Pray and Nagarajan (2010) examine if there is evidence that price controls are reducing research and development and innovation of the seed industry in India. Collecting data on the total number of seed packets sold from industry sources, they have computed revenue realized by technology providers (MMB) and seed firms in India from 2002-2010 and postulated that the implementation of price controls in 2006 was followed by an immediate, large decline in the profits of seed and biotech firms. They argue that the seed price controls in case of Bt cotton in India would benefit farmers in the short run but in the long run biotech companies may reduce their investments in research to develop or import new plant technology for India because of lower than expected or uncertain revenues from innovation. However, there is not yet any quantitative evidence that firms have reduced their research or their innovations due to the lower returns to companies that provided new biotech in India.

In contrast to the above studies, Arora and Bansal, 2012 analyze diffusion of technology in terms of actual acreage adopted under the new technology, and examine economic factors affecting them. They used a dynamic logistic model on a panel data of area under Bt cotton for 9 major cotton growing states in India, viz. Punjab, Haryana, Rajasthan, Madhya Pradesh, Maharashtra, Gujarat, Andhra Pradesh, Karnataka and Tamil Nadu from 2002-08 to study economic factors affecting diffusion of Bt cotton technology in India. The estimated percentage area under Bt cotton from this model is then used to analyze the impact of price controls on gross revenue and profitability of seed providers and predicting different scenarios. It simulates and compares gross 
revenue and profit curves under two alternative scenarios: (a) no seed price intervention, and (b) seed price intervention. Their results indicate that while seed prices significantly and negatively impact diffusion, cotton prices and number of approved varieties impact diffusion positively.

Further, Arora and Bansal (2014) analyzed the impact of seed price reductions on the revenue and profitability of seed providers. They compute the seed price elasticity of demand and found it to be highly elastic for the year 2005 (the year preceding seed price interventions). They find that the gross revenue of the seed providers increased for two consecutive years following the price controls, i.e., in 2006 and 2007. Comparing the gross revenue under two alternative scenarios, it finds that seed price reductions have increased the gross revenue of seed providers, at least in the short run. They also attempted to study regional variation of the seed price control on gross revenue. They find that the largest increase in gross revenue in the post intervention period was incurred by Gujarat, although Maharashtra is the largest cotton producing state. One possible reason behind this could be the reduction in the spread of illegal $\mathrm{Bt}$ seeds in Gujarat in the post intervention period.

Until 2008, around 75 percent of the total Bt cotton area was occupied by single gene $\mathrm{Bt}$ cotton hybrids popularly known as Bollgard $\mathrm{I}^{1}$. In later years, however, there has been a shift towards Bollgard $\mathrm{II}^{2}$ (double gene $\mathrm{Bt}$ hybrids). The percentage area under Bollgard II increased from 4 percent of the total Bt cotton area in 2006 to over 75 percent by 2011. Arora and Bansal, 2014 also brings out the dynamism that came in the Bt cotton seed market with the introduction of Bollgard II. Comparing the gross revenues of seed providers in the long run using data on actual area under Bollgard I and Bollgard II, they found that the gross revenue of seed providers from Bollgard I increased until 2008 and thereafter it declined and in the later years 2009-11, seed providers extracted more revenues from Bollgard II. Thus, they find that the price controls increased the gross revenues of seed providers in the short run, in addition, the long run witnessed the substitution in the choices of farmers from Bollgard I to Bollgard II which ultimately caused an increase in the gross revenues of seed providers.

Regarding the impact of seed price controls on profitability of seed providers, their results suggest that profits would decline with price controls only if the marginal costs of providing seeds exceed Rs 400 per acre. This scenario would be close to Pray and Nagarajan (2010) who find that profits of both seed companies as well as technology providers have reduced in the post intervention period. This suggests that the price controls could hamper the incentive of the seed providers to innovate in future and thus could restrict the

\footnotetext{
${ }^{1}$ Bollgard I is a common name given to single gene Bt Cotton hybrids. It contains the single Bt gene cry1Ac owned by Monsanto.

${ }^{2}$ Bollgard II, on the other hand are the double gene Bt cotton hybrids containing cry $1 A c$ and cry $2 A b$ genes.
}

accessibility of Indian farmers to some important new technologies.

However, if cost of producing Bt seeds is less than Rs 400 per acre then profits would increase with price controls. In that case, the government imposed price control might have improved the access of beneficial technologies to farmers without curbing the incentive of the company to innovate in the future. The results of this case are closer to Qaim and Janvry (2003) where they find that reducing the seed prices for Bt cotton in Argentina are not only beneficial for farmers but also beneficial for the seed companies. This could be possible if the seed prices in the pre intervention period were not profit maximizing prices. Thus, the overall impact of price controls on the profitability of seed providers would depend on the cost of producing $\mathrm{Bt}$ seeds.

\section{POLICY IMPLICATIONS}

The above discussion suggests that the price controls were indeed significant in impacting the diffusion of technology and increasing the gross revenue of seed providers in the short run. Arora and Bansal (2014) have argued that government imposed price controls in case of Bollgard I increased the gross revenue of seed providers in the short run for two years 2006 and 2007. However, the long run witnessed that seed providers captured the market share by practicing product differentiation and bringing a superior quality product (like double gene $\mathrm{Bt}$ hybrids). Moreover, the overall impact of these price controls on the profitability of seed providers would depend on the cost of producing $\mathrm{Bt}$ seeds.

The excessive prices charged for the official seeds may strengthen the incentive to cheat. There was widespread adoption of illegal seeds in Gujarat, which were priced between Rs 800 and Rs 1200 per packet of 450 grams as compared to a price of Rs1600 for official Bt cotton seeds (Murugkar, Ramaswami and Shelar, 2007). Thus, the government imposed price control for legal Bt seeds could have probably contributed to a reduction in the illegal Bt seeds.

However, these price controls are also one of the major challenges facing Indian firms involved in the provision of Bt cotton seed. Ag-biotech companies have to make substantial investments in research in order to develop novel traits. The price markup acts as an incentive for them to develop new technologies and therefore, in the long run, price controls could have negative implications for product development. Murugkar et al. (2007) argue that the price regulation has severely disadvantaged new entrants into the technology market, and has thus prevented price competition in the seed market. Thus, the government policies should take into account both the short run as well as long run implications of the policies.

Apart from government interventions in the pricing of Bt cotton seeds, an alternative policy measure to increase the benefits for the farmers as well as seed providers would be to allow competition among 
alternative gene providers which could reduce the seed prices on its own (rather than the government doing it) and could ultimately increase the gross revenue as well as profitability of the seed providers as a whole. The government could also encourage competition in the seed market by supporting indigenous research by farmer scientists who develop their own hybrids.

Apart from seed price controls, another policy measure for the government could be to subsidize the cost of $\mathrm{R} \& \mathrm{D}$. If government encourages public investment in $\mathrm{R} \& \mathrm{D}$ of $\mathrm{Bt}$ seeds, then it could curb monopolisation in the Bt cotton seed market. Futher, it could think of promoting successful public private partnerships in the seed industry.

\section{REFERENCES}

ARORA, A. - BANSAL, S. 2012. Diffusion of Bt Cotton in India: Impact of Seed Prices and Varietal Approval. Applied Economic Perspectives and Policy 34(1): 102118. http://dx.doi.org/10.1093/aepp/ppr038

ARORA, A. - BANSAL, S. 2014. Impact of Price Controls on Diffusion of Bt Cotton and Profitability of Seed Providers in India. In N. Lalitha and P.K. Viswanathan (Eds.): India's Tryrst with Bt Cotton: Learning from the First Decade, Concept Publishing Company Pvt. Ltd., New Delhi, pp. 156-181. (Forthcoming).

Times of India. Government raises Bt cotton seed prices. May 24 ${ }^{\text {th }}, 2011$.

LALITHA, N. 2004. Diffusion of Agricultural Biotechnology and Intellectual Property Rights: Emerging Issues in India. Ecological Economics 49(2): 187-198.

http://dx.doi.org/10.1016/j.ecolecon.2004.03.022

LALITHA, N. - PRAY, C.E. - RAMASWAMI, B. 2008. The limits of intellectual Property Rights: Lessons from the spread of Illegal transgenic Cotton seeds in India. Gujarat Institute of Development Research Working Paper No.182. Ahmedabad, India.
MINISTRY OF ENVIRONMENT AND FORESTS. 2006. Bt cotton to cover 81 lakh acres in the country by 2006. Press Information Bureau: Government of India. July 3, 2006. Accessedat:

http://pib.nic.in/newsite/PrintRelease.aspx.

MURUGKAR, M. - RAMASWAMI, B. - SHELAR, M. 2007. Competition and monopoly in the Indian cotton seed market. Economic and Political weekly 42(37): 3781-3789.

PARESH VERMA. Member of National Seed Association of India, Bt cotton seed price limit detrimental to research, Financial Express, 22 May, 2010.

PRAY, C. - NAGARAJAN, L. 2010. Price Controls and Biotechnology Innovation: Are State Government Policies Reducing Research and Innovation by the Ag Biotech Industry in India? Agbioforum 13(4): 297-307.

Accessed at: www.agbioforum.org/v13n4/v13n4a02pray. $\underline{\mathrm{htm}}$

QAIM, M., - DE JANVRY, A. 2003. Genetically modified crops, corporate pricing strategies and farmers adoption: the case of Bt cotton in Argentina. American Journal of Agricultural Economics 85(4): 814-828. http://dx.doi.org/10.1111/1467-8276.00490

SADASHIVAPPA, P. - QAIM, D. M. 2009. Bt cotton in India: Development of benefits and the role of government seed price interventions. AgBioForum 12(2): 172-183.

Accessedat:www.agbioforum.org/v12n2/v12n2a03sadashivappa.htm 